\title{
Diagnosing an 11-Year-Old Girl with Narcolepsy in a Child Psychiatry Unit: A Case Presentation
}

\section{Özlem Önen $\odot$ \\ Ayşe Kutlu (1) \\ Handan Özek Erkuran (D}

\section{Bir Çocuk Psikiyatri Biriminde 11 Yaşında Bir Kız Ön Ergene Narkolepsi Tanısı Koymak: Olgu Sunumu}

\begin{abstract}
Narcolepsy is a chronic disorder that might cause severe morbidity and functional deterioration with a wide range of complicated symptoms and without any clearly identified etiology. The condition is even more difficult to diagnose in children as clinical picture and clusters of symptoms that vary extremely. With this report, we aimed to present, and discuss an 11-year-old case diagnosed with narcolepsy in a child psychiatry unit along with relevant literature. Psychiatric assessment of the case that applied to our child psychiatry unit was carried out by using Diagnostic and Statistical Manual of Mental Disorders $5^{\text {th }}$ edition (DSM-5) criteria. Detailed clinical examination, neurological tests and imaging modalities as well as polysomnography were performed. The case was diagnosed, and followed up as having narcolepsy after completion of processes of evaluation, and differential diagnosis. She demonstrated clinical improvement with a combined treatment regimen of methylphenydate-OROS and behavioral therapy for sleep pattern and hygiene. She is still being followed up in our unit. Since narcolepsy is a rarely seen condition encountered in child psychiatry settings and symptoms might mimic other neurological and psychiatric conditions, its earlier recognition is a remote possibility. Therefore, we believe that we, as child psychiatrists, need to bear this disorder in our minds for differential diagnosis. Since current treatment options mainly target visible symptoms, developing novel treatment strategies directed towards underlying etiology will carry importance. In that sense, we believe that increasing the number of case studies and clinical researches in this understudied field of child psychiatry shall contribute greatly to more improved understanding of the disorder.
\end{abstract}

Keywords: Narcolepsy, child psychiatry, preadolescent, diagnosis, treatment

\section{öz}

Narkolepsi bir dizi karmaşık belirtiler gösteren, etiyolojisinin henüz tanımlanmamış olduğu, şiddetli morbidite ve işlev kaybı yaratabilen kronik bir bozukluktur. Narkolepsinin çocukluk döneminde tanınması fazlasıyla değişkenlik gösteren belirti kümeleri nedeni ile daha da zor olabilmektedir. Bu olgu sunumunda, çocuk psikiyatrisi birimine başvuran 11 yaşındaki bir kız olguda narkolepsinin tanılanma ve izlem sürecinin ilgili makale eşliğinde tartışılarak sunulması amaçlanmıştı. Çocuk psikiyatrisi birimimize başvuran olgunun psikiyatrik değerlendirmesi Ruhsal Bozuklukların Tanısal ve Sayımsal Elkitabı-5. baskı (DSM-5) kriterleri temel alınarak yapılmıştır. Detaylı klinik muayene, nörolojik değerlendirme ile görüntüleme teknikleri yanı sıra polisomnografi uygulanmıştır. Olgu değerlendirme ve ayırıcı tanı süreçleri tamamlandıktan sonra narkolepsi tanısı ile izleme alınmış ve metilfenidat-OROS ile uyku paterni ve hijyenine yönelik davranışsal teknikleri içeren combine tedavi ile klinik iyileşme göstermiştir. Olgu hala tarafımızca izlenmektedir. Nadir görülen bir bozukluk olan narkolepsinin çocuk psikiyatri pratiğinde daha da az görülmesi ve belirtilerin diğer nörolojik ve psikiyatrik durumları taklit edebilmesi bozukluğun erken dönemlerde tanınma olasılığını düşürmektedir. Bu nedenle çocuk psikiyatristleri olarak bizlerin bu bozukluğu ayırıcı tanı süreçlerinde aklımızda tutmamız gerektiğini düşünmekteyiz. Güncel tedavi seçeneklerinin genel olarak ortaya çıkan belirtileri düzeltmeyi hedeflediği düşünüldügünde altta yatan nedene yönelik yeni tedavi stratejilerinin gelişstirilmesi önemli olacaktır. Bu nedenle çocuk psikiyatrisi pratiğinde fazla çalışılmamış olan bu alandaki olgu sunumları ile klinik çalışmaların sayısını artırmanın klinisyenlerce bozukluğun daha iyi anlaşılmasına katkıda bulunacağına inanmaktayız.

Anahtar kelimeler: Narkolepsi, çocuk psikiyatrisi, ön ergen, tanı, tedavi
Alındığı tarih: 24.12 .2017

Kabul tarihi: 10.04.2018

Online Yayın tarihi: 14.03.2019

\author{
Handan Özek Erkuran \\ İzmir Dr. Behçet Uz Çocuk Hastalıkları \\ ve Cerrahisi Eğitim ve Araştırma \\ Hastanesi, Çocuk Psikiyatrisi Kliniği, \\ İzmir, Türkiye \\ handanozek@yahoo.com \\ ORCiD: 0000-0003-3775-0211
}

Ö. Önen 0000-0002-3633-741X

A. Kutlu 0000-0001-9359-6162 izmir Dr. Behçet Uz Çocuk Hastalıkları ve Cerrahisi Eğitim ve Araştırma Hastanesi, Çocuk Psikiyatrisi Kliniği, Izmir, Türkiye

*21. Ulusal Ergen Günleri'nde sözel bildiri olarak sunulmuştur 2016, Denizli, Türkiye 


\section{INTRODUCTION}

Narcolepsy is a chronic sleep disorder that causes significant functional deterioration. Four core clinical features are excessive daytime sleepiness with irresistible sleep episodes, cataplexy, hypnogogic or hypnopompic hallucinations and sleep paralysis ${ }^{(1)}$. Hypersomnia and irresistible sleep episodes are generally the most important baseline features ${ }^{(2)}$. Symptoms differ widely and it is reported that only $10 \%$ of the patients present with all four core features ${ }^{(3)}$. Though differences occur between countries and ethnic groups, reported prevalence is between $0.03 \%$ and $0,1^{(4)}$. There is no clear and concise information regarding prevalence of narcolepsy in childhood. In a review where 97 narcoleptic children were assessed, median age at diagnosis was 9 years, while $8 \%$ of the patients were 5 years old or younger ${ }^{(5)}$.

Among diagnostic criteria, excessive daytime sleepiness defined as irresistible episodes of sleep is mainly seen in certain times of the day and differs in each patient. Mainly, these episodes last 10-20 minutes and generally they are relaxing. These episodes might suddenly emerge in inappropriate circumstances. While symptoms might emerge as described in adults, excessive daytime sleepiness in very young children might easily be left unrecognized by health professionals and even parents ${ }^{\left({ }^{6}\right)}$.

Cataplexy is the most specific symptom of narcolepsy, seen in $60-90 \%$ of the patients. Cataplexy is defined as transient loss of muscle tonus, generally induced by an emotional stimulus ${ }^{(2)}$. Various clinical presentations have been defined; ranging from mild forms with the individual feeling the need to sit down to sudden collapse. Most cataplectic episodes last less than a minute and their frequency varies greatly, from a couple of times in a year to many times within a day ${ }^{(7)}$. Cataplexy might mimic syncope, psychogenic or atonic seizures ${ }^{(8)}$. It would be important to differentiate this condition from clinical presentation of seizures, especially in children ${ }^{(9)}$. In $30-50 \%$ of the cases with childhood narcolepsy, cataplexy does not accompany the course of the disease ${ }^{(10)}$ while in some, the phenomenon might emerge even 10 years after the diagnosis ${ }^{(11)}$.
Hypnogogic and hypnopompic hallucinations are among core clinical features and seen in approximately $60 \%$ of the cases ${ }^{(2)}$. Another significant aspect of narcolepsy is sleep paralysis that mainly occurs while falling asleep or waking up. Patients experience severe anxiety since they are unable to move at all. The phenomenon lasts for seconds to minutes and typically resolves spontaneously or when another person warns the affected individual ${ }^{(2,7)}$.

Researches that focus on etiology are increasing in number. Among these, most replicated one is low levels of hypocretine in cerebrospinal fluid (CSF) of patients with narcolepsy ${ }^{(12)}$. Hypocretine is a stimulant peptide released from posterior and lateral parts of hypothalamus ${ }^{(13)}$. Nishino et al. ${ }^{(14)}$ have reported that there was a deficiency of hypocretine peptides and a functional disruption of posterior hypothalamus which is responsible for staying awake. However, as hypocretine needs to be measured in CSF, this method has found limited grounds within diagnostic procedures in clinical practice. Increasing number of researches regarding possible underlying genetic and immunological mechanisms are being conducted.

With this paper, we aimed to present an 11-yearold girl that has applied to a child psychiatry unit due to excessive daytime sleepiness and fatigue and diagnosed with narcolepsy following clinical examination and tests, along with relevant literature information.

\section{CASE}

An 11-year-old girl applied to our unit due to falling asleep frequently during daytime, feeling tired and being unable to concentrate at school. Her complaints had started 2 years ago, and significantly increased within the previous 3-4 months and severely affected her daily functioning. She slept 3-4 times during the day, duration of each sleep episode changed between 15-20 minutes to maximum 4 hours. She started waking up at least once in the night. She started having cataplectic episodes that lasted 15-20 seconds on the street while walking which she described as "losing her balance and sense of muscular discharge". Emotional stressors did not always seem to trigger these episodes. However 
hypnogogic hallucinations accompanied clinical course at once, but decreased in number later on.

Her medical and developmental history did not reveal any clues. She was the first of three children and family members did not have any physical or psychiatric disorders. Her physical examination was normal. Her laboratory blood tests (complete blood count, liver and kidney function tests, serum electrolyte levels, urine analysis, thyroid hormone tests, vitamin B12 and folic acid levels), electroencephalography (EEG) and brain magnetic resonance imaging (MRI) results were within normal limits. As clinical assessment indicated narcolepsy among diagnostic possibilities, polysomnography (PSG), and Multiple Sleep Latency Test (MSLT) were performed which revealed short Rapid Eye Movement-Phase (REM) latency resulting in a pattern of $5 / 5$ early sleep-onset REM (So-REM). Following all procedures, diagnosis was finalized and her treatment was planned.

She was initially started on short-acting form of $\mathrm{MPH}$, twice a day. Upon adjusting its dosage, we switched to long-acting form of methylphenidate (MPH-OROS). She was also started on a behavioral therapy program that included controlled short naps twice a day, improving sleep hygiene and stress relief. With this treatment regimen, her daytime sleepiness as well as number of sleep episodes decreased and her concentration was better. In turn, she was more engaged in schoolwork and leisure activities, that positively effected her peer interactions. She is still being followed up, with a plan to carry out further genetic and immunological assessments that would hopefully provide more insight and contribute to our current understanding of the phenomenon.

\section{DISCUSSION}

Data from literature suggest that school-aged narcoleptic children experience longer sleep episodes compared to adults; whereas contrary to adults these episodes are rarely described as relaxing (15). Our case also experienced longer sleep episodes, sometimes up to 4 hours a day; however she did not wake up feeling relaxed and rejuvenated, similar to other reports in the literature. Another significant feature of narcolepsy, fragmented night sleep, frequently being mentioned in relevant literature ${ }^{(2)}$ was also observed in our case.

Cataplexy was defined in detail with DSM-5, published in 2013. With novel criteria cataplexy was defined as " a condition in children or in individuals within six months of narcolepsy onset, involuntary grimacing or jaw-opening with tongue thrusting, or hypotonia", in the absence of clear emotional triggers." (16). Our case had identified her cataplectic condition as a sudden sense of muscular discharge during walking or daily activities that lasted for a couple of minutes, not always emerging upon stimulus by an emotional trigger. Regarding four core symptoms, hypnogogic hallucinations diminished through clinical course while sleep paralysis was never described.

Regarding PSG assessment in childhood, duration of REM sleep latency needs to be under 8 minutes and so-REM (REM phase being observed within first 10 minutes of sleep) in two or more studies of MSLT need to be observed for diagnosis ${ }^{(11)}$. Presence of other symptoms does not establish the diagnosis. Indeed, sometimes excessive daytime sleepiness might be the only clinical feature indicating potential diagnosis of an early onset narcolepsy in children making it much more difficult to recognize the phenomenon. Luckily, our case presented with cataplectic episodes along with excessive daytime sleepiness, hypnogogic hallucinations and fragmented sleep; therefore, we were able to detect and identify these symptoms so as to start a set of diagnostic procedures for narcolepsy.

As researches directed towards identifying etiology of narcolepsy continue, current treatment options aim symptomaticimprovement. Methylphenidate and modafinil are the two most commonly used agents for controlling excessive daytime sleepiness and sleep episodes. Both drugs act through mediating dopamine. Modafinil is less commonly chosen for children and used even less due to reported scarce, however serious side effects such as StevenJohnson syndrome, suicide attempts and psychosis (17). Sodium oxybate is a novel agent that has recently started being used; however due to severe and multiple side effects ranging from nausea to delirium 
and potential risk of misuse as it causes euphoria in higher doses, its use has not been widely suggested, especially in children ${ }^{(18,19)}$. Tricyclic antidepressants (TCAs) and Selective Serotonin Reuptake Inhibitors (SSRIs) are also well known to have positive effect on cataplexy ${ }^{(18,19)}$. Increased daytime sleepiness, orthostatic hypotension, weight gain, loss of appetite, diarrhea, dry mouth are among identified side effects of TCA and relative increase in the risk of status epilepticus following abrupt cessation of the drug as well ${ }^{(18,19)}$. Behavioral techniques as inducing controlled short naps once or twice during the day that last less than 30 minutes to prevent entering deep slowwave sleep have been reported to yield positive outcomes as well ${ }^{(20,21)}$. Our case also benefited from combination of behavioral therapy and stimulant medication.

\section{CONCLUSION}

As narcolepsy is a less common condition encountered in child psychiatry settings and symptoms might mimic other neurological and psychiatric conditions, which in turn, decreases the odds for the recognition of early onset disease, we believe that we, as child psychiatrists, need to bear this disorder in our minds for differential diagnosis. Since current treatment options mainly target visible symptoms, developing novel treatment strategies directed towards underlying etiology will convey importance. In that sense, we believe that increasing the number of case studies and clinical researches in this understudied field of child psychiatry will contribute greatly to a better understanding of the disorder.

\section{REFERENCES}

1. American Academy of Sleep Medicine. The International Classification of Sleep Disorders, Diagnostic and Coding Manual. 3rd ed. Darien, IL: American Academy of Sleep Medicine; 2014.

2. Dauvilliers Y, Arnulf I, Mignot E. Narcolepsy with cataplexy. Lancet. 2007;369:499-511. https://doi.org/10.1016/S0140-6736(07)60237-2

3. Morrish E, King MA, Smith IE, Shneerson JM. Factors associated with a delay in the diagnosis of narcolepsy. Sleep Med. 2004;5:37-41.

https://doi.org/10.1016/j.sleep.2003.06.002
4. Turgut N. Narkolepsi-katapleksi sendromu. Trakya Üniversitesi Tıp Fakültesi Dergisi. 2003;20:47-53.

5. Challamel MJ, Mazzola ME, Nevsimalova S, Cannard C, Louis J, Revol M. Narcolepsy in children. Sleep. 1994;17(Suppl. 8):17-20. https://doi.org/10.1093/sleep/17.suppl_8.S17

6. Guilleminault C, Pelayo R. Narcolepsy in prepubertal children. Ann Neurol. 1998;43:35-42. https://doi.org/10.1002/ana.410430125

7. Burgess CR, Scammell TE. Narcolepsy: neural mechanisms of sleepiness and cataplexy. J Neurosci. 2012;32:12305-11. https://doi.org/10.1523/JNEUROSCI.2630-12.2012

8. Yilmaz K, Uyar M, Adaletli H, Kilincaslan A. Diagnostic pitfalls in children with sleep disorders: two cases with hypersomnia. Acta Paediatr. 2008;97:1749-51. https://doi.org/10.1111/j.1651-2227.2008.00991.x

9. Şenel GB, Karadeniz D. A Case Report of Narcolepsy with Partial Cataplexy Misdiagnosed as Epilepsy. Journal of Turkish Sleep Medicine. 2015;1:22-4. https://doi.org/10.4274/jtsm.02.006

10. Kotagal S. Narcolepsy in children. Semin Pediatr Neurol. 1996;3:36-43. https://doi.org/10.1016/S1071-9091(96)80027-1

11. Nevsimalova S. Narcolepsy in childhood. Sleep Med Rev. 2009;13:169-80. https://doi.org/10.1016/j.smrv.2008.04.007

12. Nishino S, Ripley B, Overeem S, Nevsimalova S, Lammers GJ, Vankova J, Mignot E. Low cerebrospinal fluid hypocretin (Orexin) and altered energy homeostasis in humannarcolepsy. Ann Neurol. 2001;50:381-8. https://doi.org/10.1002/ana.1130

13. De Lecea L, Kilduff TS, Peyron C, Gao XB, Foye PE, Danielson $P E$, Frankel WN. The hypocretins: hypothalamus specific peptides with neuroexcitatory activity. Proc Natl Acad Sci USA. 1998;95:322-327.

https://doi.org/10.1073/pnas.95.1.322

14. Nishino S, Ripley B, Overeem S, Lammers GJ, Mignot E. Hypocretin (orexin) deficiency in human narcolepsy. Lancet. 2000;355:39-40. https://doi.org/10.1016/S0140-6736(99)05582-8

15. Nevsimalova S, Pretl M, Vankova J. Narcolepsy in children and adolescents. In: Evrard P, Richelme C, Tardieu M (eds.) 3rd EPNSCongress. Bologna:Monduzzi; p73-77; 1999.

16. American Psychiatric Association. Diagnostic and Statistical Manual of Mental Disorders, $5^{\text {th }}$ ed. (DSM-5).Washington, DC: American Psychiatric Association; 2013.

17. Lavault S, Dauvilliers Y, Drouot X, Leu-Semenescu S, Golmard $\mathrm{JL}$, Lecendreux $\mathrm{M}$, Arnulf $\mathrm{I}$. Benefit and risk of modafinil in idiopathic hypersomnia vs. narcolepsy with cataplexy. Sleep Med. 2011;12:550-6. https://doi.org/10.1016/j.sleep.2011.03.010

18. Didato G, Nobili L. Treatment of narcolepsy. Expert Rev Neurother. 2009;9:897-910. https://doi.org/10.1586/ern.09.29

19. De la Herrán-Arita AK, García-García F. Current and emerging options for the drug treatment of narcolepsy. Drugs. 2013;73:1771-81. https://doi.org/10.1007/s40265-013-0127-y

20. Billiard M, Bassetti C, Dauvilliers Y, Dolenc-Groselj L, Lammers GJ, Mayer G, Sonka K. EFNS guidelines on management of narcolepsy. Eur J Neurol. 2006;13:1035-48. https://doi.org/10.1111/j.1468-1331.2006.01473.x

21. Billiard M. Narcolepsy: Current treatment options and future approaches. Neuropsychiatr Dis Treat. 2008;4:557-66. 